\title{
Underweight and Its Predictors Among Patients on Anti Retroviral Therapy at Selected Health Facilities of Addis Ababa, Ethiopia, 2020
}

This article was published in the following Dove Press journal: HIVIAIDS - Research and Palliative Care

\author{
Addisu Tadesse Sahile (D) \\ Solomon Muluken Ayehu (D) ${ }^{2}$ \\ Selamawit Fekadu Fanta ${ }^{3}$ \\ 'Department of Public Health, Unity \\ University, Addis Ababa, Ethiopia; \\ ${ }^{2}$ Department of Emergency, Menelik II \\ Referral Hospital, Addis Ababa, Ethiopia; \\ ${ }^{3}$ Department of ICU, Saint Peter \\ Specialized Hospital, Addis Ababa, \\ Ethiopia
}

Objective: The study aimed at assessing the prevalence of underweight and its predictors in patients on ART, in health facilities of Addis Ababa, Ethiopia, 2020.

Methods: A multi-center-based cross-sectional study was conducted among 319 patients on ART selected on the basis of stratified sampling method in Addis Ababa from July 01 to August 30, 2020. An interviewer-administered structured questionnaire was used for collection of the data, after which informed consent was obtained from all the included participants. Descriptive statistics for the summarization of the data was used. Binary (Bivariate and multivariate) logistics regression was applied for the identification of predictors of underweight and its strength of association with their respective 95\% confidence intervals and less than $5 \%$ p-values as statistically significant association.

Findings: The prevalence of underweight among patients on ART was $19.1 \%(95 \% \mathrm{CI}$ : $15.0-23.9 \%)$, while more than one-tenth $(14.4 \%)$ of the participants were overweight $(95 \%$ CI: 10.8-18.8\%). A higher level of Educational level, being married, widowed, divorced, a lower family size and poor ART drug adherence level were statistically significantly associated with an increased risk of underweight among patients on ART in the study settings $(\mathrm{p}<0.05)$.

Conclusion: Educational level, marital status, family size, and adherence status of the participants were identified predictors of underweight among patients on ART. The lower the educational level, lower family size, being either married, divorced, or widowed, having had of poor ART drug adherence level of the participants, the higher their risk of sustaining underweight. Concerned bodies were suggested to work over the identified determinants of underweight among patients on ART in the study settings.

Keywords: underweight, predictors, ART
Correspondence: Addisu Tadesse Sahile Tel +2519 I2096667

Email sahdis91@gmail.com

\section{Introduction}

Acquired Immune Deficiency Syndrome (AIDS) is a disease caused by Human Immunodeficiency Virus (HIV). ${ }^{1-6}$ Globally, the HIV is the top cause of morbidity and mortality, whereby 36.7 million people had AIDS with more than a million AIDS-related deaths by the year 2016. ${ }^{7,8}$ Globally, 38 million people were living with HIV, and the rate of new infection was 1.7 million in 2019. ${ }^{9}$

Combination therapy (ART) had a greater efficacy at suppressing HIV replication, reducing HIV-related death and morbidity, and improving immune function. ${ }^{10-12}$ The issue of access to these drugs could unquestionably be the top priority of the global community, where about 12 million people have been 
receiving the drugs $(\mathrm{ART})^{13}$ with an increased effort to raise the coverage of the treatment to all individuals who were seropositive. In the effort to decentralize and scale-up the service, there were increased centers delivering the service in most parts of Ethiopian Health institutions. ${ }^{13}$

Globally, more than 800 million people are undernourished, ${ }^{14}$ the combination of malnutrition with HIV/AIDS, resulted in a significant crisis throughout the world. In developing countries, the concomitant occurrence of infectious disease with malnutrition accelerated for the morbidities and mortality following the exacerbated HIV/AIDS pandemic. ${ }^{15-17}$

As reported in different kinds of literature people with HIV are at an increased risk of undernutrition due to poor appetite, and reduced absorption of nutrients. ${ }^{18-20}$ In Ethiopia, the prevalence of undernutrition was reported up to $43 \%{ }^{21}$

Though nutritional services for people living with HIV were advocated in Ethiopia, there is scantiness of information on the level of undernutrition among people on ART. $^{22}$ To the best of the researcher's knowledge, there is limited knowledge on the burden and determinants of undernutrition (underweight) in Ethiopia. Hence, this study was aimed at assessing the magnitude and determinants of underweight among patients on ART in health facilities in Addis Ababa, Ethiopia, 2020.

\section{Methods}

\section{Participants and Study Design}

A multicenter-based cross-sectional study design was conducted on 319 participants on ART at the purposively selected health centers from July 01 to August 30, 2020. The study received ethical approval from Addis Ababa Medical and Business College research review ethics committee and applied for the respective health institutions. All participants were provided written informed consent. The source population was all ART patients that had a follow- up the four selected health facilities, namely Arada Health center, Semien Health Center, Afincho Ber Health Center, and Churchill Health center. The study population was the 319 participants included in the study from those available during the data collection period. The sample was determined based on single population proportion, with the premises that the prevalence of underweight from the study at Butajira was $25.2 \%,{ }^{23} 95 \%$ confidence intervals 1.96 , and a $5 \%$ margin of error, the final sample comes 3019 inclusive of 5\% nonresponse rate. Patients on ART for at least 6 months, older than 18 years old, and not severely ill were included in the study. A stratified sampling technique was applied for the selection of the study participants proportionally (Figure 1).

Data were gathered with a pre-tested intervieweradministered questionnaire. The questionnaire was developed by reviewing related literatures ${ }^{10,15,19,20,22}$ then given to two senior researchers working in academic institutions to incorporate their possible inputs.

\section{Operational Definition}

The outcome variable (underweight) was measured by body mass index (BMI), where the variable was grouped as underweight if BMI is less than $18.5 \mathrm{~kg} / \mathrm{m}^{2}$, normal weight if BMI is $18.5-24.9 \mathrm{~kg} / \mathrm{m}^{2}$, and as overweight if greater than $25 \mathrm{~kg} /$ $\mathrm{m}^{2}{ }^{10}$ For the current study, underweight was measured similarly someone with a BMI of less than $18.5 \mathrm{~kg} / \mathrm{m}^{2}$.

Good adherence: if the average adherence is greater than $95 \%$ (if missed $\leq 2$ doses of 30 doses or $\leq 3$ doses of 60 doses). ${ }^{23}$

Fair adherence: if the average adherence is $85 \%$ to $94 \%$ (if missed 2-5 doses of 30 doses or 3-9 doses of 60 doses). ${ }^{23}$

Poor adherence: if the average adherence is less than $85 \%$ (if missed $\geq 6$ doses of 30 doses or $>9$ doses of 60 doses). ${ }^{23}$

\section{Statistical Analysis}

Descriptive statistics were used for the summarization of data. For the identification predictors of underweight

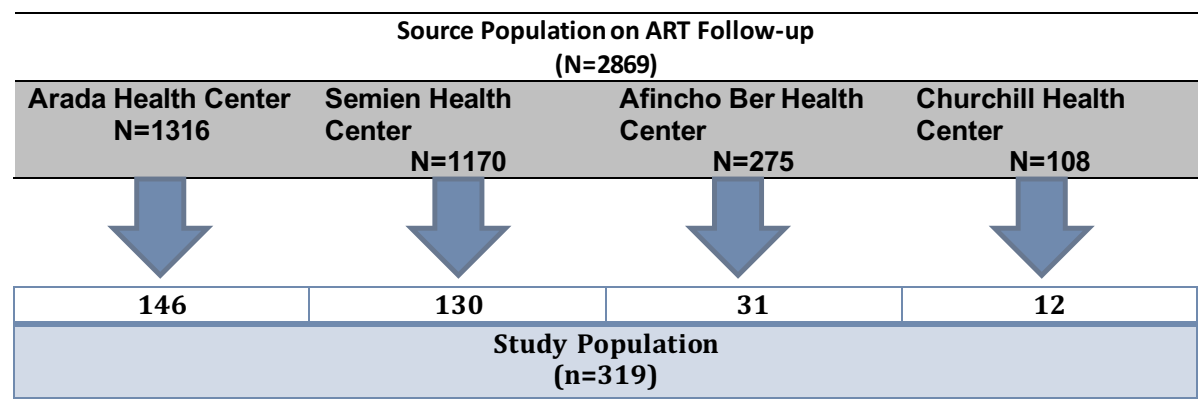

Figure I Sampling procedure of the participants for the study, Addis Ababa, Ethiopia, 2020. 
Table I Socio-Demographic Characteristics of Patients on ART at the Selected Health Facilities in Addis Ababa, Ethiopia, 2020

\begin{tabular}{|c|c|c|c|c|}
\hline Characteristics & Options & Underweight N(\%) & Normal Weight N(\%) & Overweight $\mathbf{N}(\%)$ \\
\hline \multirow[t]{2}{*}{ Sex } & Male & $10(3.13)$ & $55(17.23)$ & $18(5.64)$ \\
\hline & Female & $5 I(16.00)$ & $157(49.21)$ & $28(8.77)$ \\
\hline \multirow[t]{3}{*}{ Age in years } & $\leq 30$ & $27(8.46)$ & $66(20.69)$ & $9(2.8 I)$ \\
\hline & $31-40$ & $23(7.21)$ & $112(35.10)$ & $24(7.52)$ \\
\hline & $\geq 41$ & II (3.44) & $34(10.66)$ & $13(4.07)$ \\
\hline \multirow[t]{5}{*}{ Educational status } & No formal education & $4(1.25)$ & $35(10.97)$ & $5(1.56)$ \\
\hline & Primary school & $29(9.09)$ & $86(26.96)$ & $22(6.89)$ \\
\hline & Secondary school & $14(4.39)$ & $61(19.12)$ & $16(5.02)$ \\
\hline & Diploma & $13(4.07)$ & $21(6.58)$ & $I(0.3 I)$ \\
\hline & Degree and above & $\mathrm{I}(0.3 \mathrm{I})$ & $9(2.82)$ & $2(0.63)$ \\
\hline \multirow[t]{6}{*}{ Occupation } & Student & $5(1.56)$ & $12(3.76)$ & $3(0.94)$ \\
\hline & Government employee & $15(4.70)$ & $55(17.24)$ & I4(4.39) \\
\hline & Daily laborer & |4(4.39) & $64(20.06)$ & $13(4.07)$ \\
\hline & Self-employee & I4(4.39) & $50(15.67)$ & II (3.44) \\
\hline & Housewife & $3(0.94)$ & $17(5.33)$ & $2(0.63)$ \\
\hline & No job & $10(3.13)$ & 14(4.39) & $3(0.94)$ \\
\hline \multirow[t]{4}{*}{ Marital status } & Unmarried & $12(3.76)$ & $63(19.75)$ & $9(2.82)$ \\
\hline & Married & $25(7.84)$ & $83(26.02)$ & $18(5.64)$ \\
\hline & Divorced & $12(3.76)$ & $33(10.34)$ & $7(2.19)$ \\
\hline & Widowed & $12(3.76)$ & $33(10.34)$ & $12(3.76)$ \\
\hline \multirow[t]{3}{*}{ Family size } & $\leq 3$ & $38(11.91)$ & $116(36.36)$ & $24(7.52)$ \\
\hline & $4-5$ & $19(5.96)$ & $76(23.82)$ & $18(5.64)$ \\
\hline & $\geq 6$ & $4(1.25)$ & $20(6.27)$ & $4(1.25)$ \\
\hline
\end{tabular}

among ART patients, binary (bi-variable and multivariable) logistics regression was used, with their respective $95 \%$ confidence interval (CI) and p-value of less than 0.05 as statistically significant level.

\section{Findings}

\section{Socio-Demographic Characteristics}

A total of 3019 participants enrolled to the study with a response rate of $100 \%$. Half $(49.21 \%)$ of the female participants had a normal BMI, with more than one-third $(35 \%)$ of the participants with a normal BMI were those in the age group of $31-40$ years. More than one-third $(36.36 \%)$ of the study participants with a normal BMI were those with a family size of three or fewer (Table 1).

\section{Diet-Related Characteristics}

Regarding the dietary-related features of the study participants, more than half $(54.9 \%)$ had a 24 -hour meal frequency of three or more times, most $(82.8 \%)$ did not receive any food support, and most $(63.9 \%)$ of the study participants received of dietary counseling. Whereas
$91.8 \%$ of the study participants reported they consumed of cereals-wheat, rice, sorghum, millet and bread, with $77.1 \%$ of the study participants received of vegetables in the last 24 hours (Table 2).

\section{ART Drug and Side Effects}

Less than half $(41.7 \%)$ of the study participants' current CD4 count was greater than 500 cells $/ \mathrm{mm}^{3}$, with a viral load count of less than 1000 copy cells $/ \mathrm{mm}^{3}$ in the $74.3 \%$ of the cases. Most $(60 \%)$ of the study participants started ART drugs within the duration of 2-5 years, where more than half $(53.3 \%)$ took le(TDF+3TC+EFV) and $71 \%$ of the study participants had good drug adherence (Table 3 ).

\section{Prevalence of Underweight Among Patients on ART}

The prevalence of underweight among ART patients on follow-up was $19.1 \%$ (95\% CI: $15.0-23.9 \%)$, while more than one-tenth $(14.4 \%)$ of the participants were overweight (Table 4). 
Table 2 Diet-Related Characteristics of Patients on ART at the Selected Health Facilities in Addis Ababa, Ethiopia, 2020

\begin{tabular}{|c|c|c|c|}
\hline Characteristics & Categories & Frequency & $\%$ \\
\hline \multirow[t]{3}{*}{ Meal frequency pattern in the last 24 hours } & Three meals and above & 175 & 54.9 \\
\hline & Less than three meals & 123 & 38.6 \\
\hline & I do not remember & 21 & 6.6 \\
\hline \multirow[t]{2}{*}{ Ever received food support } & Yes & 55 & 17.2 \\
\hline & No & 264 & 82.8 \\
\hline \multirow[t]{4}{*}{ Type of support obtained } & Food production & 38 & 11.9 \\
\hline & Money & 4 & 1.3 \\
\hline & Clothing & 13 & 4.1 \\
\hline & No & 264 & 82.8 \\
\hline \multirow[t]{4}{*}{ Duration of food support } & $\leq 1$ months & 2 & 0.6 \\
\hline & I-3 months & 12 & 3.8 \\
\hline & $\geq 3$ months & 41 & 12.9 \\
\hline & No & 264 & 82.8 \\
\hline \multirow[t]{2}{*}{ Ever received a dietary counseling } & Yes & 204 & 63.9 \\
\hline & No & 115 & 36.1 \\
\hline \multirow[t]{10}{*}{ Received of the following in the past 24 hours } & Cereals, rice, wheat, sorghum, millet, bread, porridge & 293 & 91.8 \\
\hline & White tubers and roots & 172 & 53.9 \\
\hline & Dark green leafy vegetables & 135 & 42.3 \\
\hline & Vegetables (tomato,onion, eggplant) & 246 & 77.1 \\
\hline & Vitamin-rich diet & 80 & 25.1 \\
\hline & Flesh meat & 107 & 33.5 \\
\hline & Eggs & 97 & 30.4 \\
\hline & Fish & 26 & 8.2 \\
\hline & Legumes, nuts and seeds & 172 & 53.9 \\
\hline & Milk products & 74 & 23.2 \\
\hline
\end{tabular}

\section{Predictors of Underweight Among Participants on ART}

The age and educational level of the participants were variables that were independently associated with underweight among patients on ART. In multivariable logistics regression, educational level, marital status, family size and adherence status were predictors statistically associated with underweight among patients on ART.

The odds of developing underweight was $97.6 \%$, $91.2 \%$, and $88.1 \%$ higher among participants with an educational level of college and above (AOR: 0.024, 95\% CI: $0.002,0.233, \mathrm{P}<0.001$ ), primary school (AOR: $0.088,95 \% \mathrm{CI}: 0.010,0.744, \mathrm{P}<0.05)$, and secondary school (AOR: 0.119, 95\% CI: 0.014, 0.997, P<0.05) compared with illiterate participants, respectively.

The risk of developing underweight was higher by 78.8\% (AOR: 0.212, 95CI: 0.072, 0.619, $\mathrm{P}<0.05$ ), 71.2\% (AOR: $0.288,95 \%$ CI: $0.093,0.894, \mathrm{P}<0.05$ ) and $67.3 \%$ (AOR: 0.327, 95\% CI: 0.132, 0.813, $\mathrm{P}<0.05$ ), among divorced, widowed and married participants consecutively.
The odds of developing underweight was almost three times higher among participants with a family size of three and less compared with those with four and more family size (AOR: 2.680, 95\% CI: 1.254, 5.727, $\mathrm{P}<0.05$ ) and the risk of developing underweight was higher at $98 \%$ among participants with poor drug adherence compared with those participants with good adherence (AOR: 0.020, 95\% CI: 0.001, 0.290, $\mathrm{P}<0.05$ ). (Table 5)

\section{Discussion}

In this study, the prevalence of underweight among patients on ART was $19.1 \%$, this was consistent with the findings of $23.72 \%$ in Arba Minch, Southern Ethiopia, ${ }^{24}$ $23.2 \%$ in Gonder, Northwest Ethiopia, ${ }^{10} 23.6 \%$ in West Showa, Central Ethiopia, ${ }^{25} 19.93 \%$ in Kathmandu Valley, $\mathrm{Nepal}^{26}{ }^{26} 19.2 \%$ to $26.3 \%$ in Senegal ${ }^{27}$ and $19.4 \%$ in Temeke, Tanzania. ${ }^{28}$

The prevalence of underweight among patients on ART in this study was lower than the findings $27 \%$ in Wollega, 
Table 3 ART Drug and Its Side Effects Among Patients on ART at the Selected Health Facilities in Addis Ababa, Ethiopia, 2020

\begin{tabular}{|c|c|c|c|}
\hline Characteristics & Categories & Number & $\%$ \\
\hline \multirow[t]{4}{*}{ Current CD4 count } & $<200$ cells $/ \mathrm{mm}^{3}$ & 12 & 3.8 \\
\hline & 200-349 cells $/ \mathrm{mm}^{3}$ & 65 & 20.4 \\
\hline & $350-499$ cells $/ \mathrm{mm}^{3}$ & 109 & 34.2 \\
\hline & $>500$ cells $/ \mathrm{mm}^{3}$ & 133 & 41.7 \\
\hline \multirow[t]{2}{*}{ Current viral load count } & $<1000$ copy cells $/ \mathrm{mm}^{3}$ & 237 & 74.3 \\
\hline & $>1000$ copy cells $/ \mathrm{mm}^{3}$ & 82 & 25.7 \\
\hline \multirow[t]{3}{*}{ WHO clinical staging } & Stage I & 274 & 85.9 \\
\hline & Stage 2 & 35 & 11.0 \\
\hline & Stage 3 & 10 & 3.1 \\
\hline \multirow[t]{4}{*}{ Duration since start of ART } & $\leq \mathrm{I}$ year & 9 & 2.8 \\
\hline & $2-5$ years & 190 & 59.6 \\
\hline & $6-10$ years & 70 & 21.9 \\
\hline & $\geq 10$ years & 50 & 15.7 \\
\hline \multirow[t]{5}{*}{ Current ART regimen } & $\mathrm{Ic}(\mathrm{AZT}+3 \mathrm{TC}+\mathrm{NVP})$ & 61 & 19.1 \\
\hline & $\mathrm{Id}(\mathrm{AZT}+3 \mathrm{TC}+\mathrm{EFV})$ & 34 & 10.7 \\
\hline & le(TDF+3TC+EFV) & 170 & 53.3 \\
\hline & If(TDF+3TC+NVP) & 24 & 7.5 \\
\hline & $\mathrm{Ij}(T D F+3 T C+D T G)$ & 30 & 9.4 \\
\hline \multirow[t]{3}{*}{ Adherence level } & Good adherence & 228 & 71.5 \\
\hline & Fair adherence & 84 & 26.3 \\
\hline & Poor adherence & 7 & 2.2 \\
\hline \multirow[t]{5}{*}{ Any side effects in the last six months } & Neuropath & 31 & 9.7 \\
\hline & Hepatotoxicity & 5 & 1.6 \\
\hline & Rash & 67 & 21.0 \\
\hline & Other & 13 & 4.1 \\
\hline & No & 203 & 63.6 \\
\hline \multirow[t]{5}{*}{ Opportunistic Infection in the last 6 months } & Acute/chronic diarrhea & 30 & 9.4 \\
\hline & Mouth sort and ulcer & 54 & 16.9 \\
\hline & Tuberculosis & 8 & 2.5 \\
\hline & Herpes zoster & 10 & 3.1 \\
\hline & No & 217 & 68.0 \\
\hline
\end{tabular}

Table 4 Prevalence of Underweight Among Patients on ART at the Selected Health Facilities in Addis Ababa, Ethiopia, 2020

\begin{tabular}{|l|l|l|l|}
\hline Characteristics & Categories & Frequency(Percent) & $\mathbf{9 5 \% ~ C l ~}$ \\
\hline BMI & $\leq 18.49 \mathrm{~kg} / \mathrm{m}^{2}$ & $6 I(19.1)$ & $15.0-23.9 \%$ \\
& $18.5-24.49 \mathrm{~kg} / \mathrm{m}^{2}$ & $212(66.5)$ & $61.0-71.6 \%$ \\
& $\geq 24.50 \mathrm{~kg} / \mathrm{m}^{2}$ & $46(14.4)$ & $10.8-18.8 \%$ \\
\hline Underweight & Yes & $6 I(19.1)$ & $15.0-23.9 \%$ \\
& No & $258(80.9)$ & $76.1-85.0 \%$ \\
\hline
\end{tabular}

Western Ethiopia, ${ }^{22} 30 \%$ in Harerge, Eastern Ethiopia, ${ }^{29}$ $27 \%$ in Jimma, Southeastern Ethiopia, ${ }^{30} 26.6 \%$ in Wolaita Sodo, Southern Ethiopia, ${ }^{31} 31.2 \%$ in Hosanna, Southern Ethiopia, ${ }^{32}$ and $43 \%$ in Brazil. ${ }^{33}$ The variation might be due to the variability of time of investigation and sample size among the studies.

The prevalence of underweight among participants on ART in Dilla Referral Hospital, Southern Ethiopia was 
Table 5 Predictors of Underweight Among Patients on ART at the Selected Health Facilities in Addis Ababa, Ethiopia, 2020

\begin{tabular}{|c|c|c|c|c|c|}
\hline \multirow[t]{2}{*}{ Characteristics } & \multirow[t]{2}{*}{ Categories } & \multicolumn{2}{|c|}{ Underweight } & \multirow[t]{2}{*}{$\operatorname{COR}(95 \% \mathrm{Cl})$} & \multirow[t]{2}{*}{ AOR(95\% CI) } \\
\hline & & Yes & No & & \\
\hline Sex & $\begin{array}{l}\text { Male } \\
\text { Female }\end{array}$ & $\begin{array}{l}10 \\
51\end{array}$ & $\begin{array}{l}73 \\
185\end{array}$ & $\begin{array}{l}\text { I } \\
0.497(0.239,1.031)\end{array}$ & $\begin{array}{l}\text { I } \\
0.802(0.338, I .907)\end{array}$ \\
\hline Age in years & $\begin{array}{l}\leq 30 \\
31-40 \\
\geq 41\end{array}$ & $\begin{array}{l}27 \\
23 \\
11\end{array}$ & $\begin{array}{l}75 \\
136 \\
47\end{array}$ & $\begin{array}{l}\text { I } \\
2.129(I .14 I, 3.97 I)^{*} \\
1.538(0.698,3390)\end{array}$ & $\begin{array}{l}\text { I } \\
\text { I.49|(0.7I5,3.II2) } \\
\text { I.II I (0.378,3.285) }\end{array}$ \\
\hline Educational level & $\begin{array}{l}\text { Illiterate } \\
\text { Primary } \\
\text { Secondary } \\
\text { College and above }\end{array}$ & $\begin{array}{l}5 \\
29 \\
14 \\
13\end{array}$ & $\begin{array}{l}40 \\
108 \\
77 \\
22\end{array}$ & $\begin{array}{l}\text { I } \\
0.372(0.123, I .126) \\
0.550(0.170, I .78 I) \\
0.169(0.049,0.582)^{*}\end{array}$ & $\begin{array}{l}\text { I } \\
0.088(0.010,0.744)^{*} \\
0.119(0.014,0.997)^{*} \\
0.024(0.002,0.233)^{* *}\end{array}$ \\
\hline Marital status & $\begin{array}{l}\text { Un married } \\
\text { Married } \\
\text { Divorced } \\
\text { Widowed }\end{array}$ & $\begin{array}{l}12 \\
25 \\
12 \\
12\end{array}$ & $\begin{array}{l}72 \\
101 \\
40 \\
45\end{array}$ & $\begin{array}{l}\text { I } \\
0.673(0.317, I .428) \\
0.556(0.228, I .35 I) \\
0.625(0.259, I .5 I I)\end{array}$ & $\begin{array}{l}\text { I } \\
0.327(0.132,0.813)^{*} \\
0.212(0.072,0.619)^{*} \\
0.288(0.093,0.894)^{*}\end{array}$ \\
\hline Family size & $\begin{array}{l}\leq 3 \\
\geq 4\end{array}$ & $\begin{array}{l}38 \\
23\end{array}$ & $\begin{array}{l}140 \\
118\end{array}$ & $\begin{array}{l}\text { I } \\
\text { I.393(0.785,2.469) }\end{array}$ & $\begin{array}{l}\text { I } \\
2.680(1.254,5.727)^{*}\end{array}$ \\
\hline Received food Support & $\begin{array}{l}\text { Yes } \\
\text { No }\end{array}$ & $\begin{array}{l}14 \\
47\end{array}$ & $\begin{array}{l}41 \\
217\end{array}$ & $\begin{array}{l}\text { I } \\
\text { I.577(0.796,3.124) }\end{array}$ & $\begin{array}{l}\text { I } \\
\text { I.796(0.8II,3.976) }\end{array}$ \\
\hline Received dietary counseling & $\begin{array}{l}\text { Yes } \\
\text { No }\end{array}$ & $\begin{array}{l}44 \\
17\end{array}$ & $\begin{array}{l}160 \\
98\end{array}$ & $\begin{array}{l}\text { I } \\
\text { I.585(0.858,2.928) }\end{array}$ & $\begin{array}{l}\text { I } \\
\text { I.500(0.7I5,3.147) }\end{array}$ \\
\hline Viral load & $\begin{array}{l}<1000 \text { copy cells } / \mathrm{mm}^{3} \\
>1000 \text { copy cells } / \mathrm{mm}^{3}\end{array}$ & $\begin{array}{l}41 \\
20\end{array}$ & $\begin{array}{l}196 \\
62\end{array}$ & $\begin{array}{l}\text { I } \\
0.648(0.354,1.189)\end{array}$ & $\begin{array}{l}\text { I } \\
0.612(0.270,1.387)\end{array}$ \\
\hline Adherence status & $\begin{array}{l}\text { Good adherence } \\
\text { Fair adherence } \\
\text { Poor adherence }\end{array}$ & $\begin{array}{l}40 \\
18 \\
3\end{array}$ & $\begin{array}{l}188 \\
66 \\
4\end{array}$ & $\begin{array}{l}\text { I } \\
0.780(0.4 \mid 8, I .455) \\
0.284(0.06 I, I .317)\end{array}$ & $\begin{array}{l}\text { I } \\
0.54 I(0.238, I .230) \\
0.020(0.00 I, 0.290)^{*}\end{array}$ \\
\hline
\end{tabular}

Notes: ${ }^{*} p<0.05,{ }^{*} \mathrm{p}<0.001$ - statistically significant association.

$12.3 \%,{ }^{34}$ which was lower than the findings of the current study. This might be due to variations in the characteristic of the population. And the magnitude of underweight among patients on ART from this study was higher than the findings $10 \%$ in Zimbabwe. ${ }^{35}$ The difference might be associated with differences in the population and sample size between the studies.

In this study, predictors of underweight were educational level, marital status, family size, and adherence status of the participants. Accordingly, the prevalence of underweight was higher among participants with some level of education compared to those of illiterates, whereas in the other study a higher educational level was associated with a reduced risk of underweight. ${ }^{36}$

In this study, having a fewer number of family size was associated with a higher risk of underweight. But in the other study having had a larger family size was associated with an increased risk of underweight compared to having less family size ${ }^{37}$ In this study, good drug adherence was associated with a lower risk of underweight which was also supported by the other findings. ${ }^{38,39}$

\section{Conclusion and Recommendation}

This study reported a higher prevalence of underweight. As predictors of underweight among patients on ART, educational level, marital status, family size, and adherence status of the participants were identified. The lower the educational level, lower family size, being either married, divorced, or widowed, having had of poor ART drug adherence level of the participants, the higher their risk of sustaining underweight.

Policymakers, health professionals, and key stakeholders were recommended to work on the identified predictors of underweight among patients on ART in the study settings. 


\section{Limitation of the Study}

The study was a cross-sectional study, that had a nature of point observation and difficult to establish the temporal association between variables. The other limitation was difficulty of inferring to the community at large as it was institution-based study.

\section{Abbreviations}

AOR, adjusted odds ratio; ADIS, acquired deficiency immune syndrome; ART, antiretroviral therapy; BMI, body mass index; COR, crude odds ratio; HAART, highly active antiretroviral therapy; HIV, human immune virus; PLWHA, people living with HIV/ADIS; WHO, World Health Organization.

\section{Data Sharing Statement}

A finding of this study was generated from the data collected and analyzed on the basis of stated methods and materials hence all data were already available in the manuscript.

\section{Ethics Approval and Consent to Participate}

The study protocol was performed in accordance with the ethical principle. Ethical approval was obtained from the ethics review Committee of Addis Ababa Medical and Business College. The ethics approval was given in accordance with the Declaration of Helsinki. The data collectors obtained written informed consent from all participants.

\section{Consent for Publication}

Consent for publication of the manuscript was not applicable due to the fact that there were no participant's individual data videos or images.

\section{Acknowledgments}

The authors would also thank study participants for their willingness in taking part in the study. The researchers would like to express their gratitude to data collectors.

\section{Author Contributions}

All authors made substantial contributions to conception and design, acquisition of data, or analysis and interpretation of data; took part in drafting the article or revising it critically for important intellectual content; agreed to submit to the current journal; gave final approval of the version to be published; and agree to be accountable for all aspects of the work.

\section{Funding}

The authors received no specific funding for this work.

\section{Disclosure}

The authors declare that there is no competing interest.

\section{References}

1. Wiley CA, Schrier RD, Nelson JA, Lampert PW, Oldstone M. Cellular localization of human immunodeficiency virus infection within the brains of acquired immune deficiency syndrome patients. Proc Natl Acad Sci U S A. 1986;83(18):7089-7093. doi:10.1073/ pnas.83.18.7089

2. Blattner W, Gallo RC, Temin H. HIV causes aids. Science. 1988;241 (4865):515-516. doi:10.1126/science.3399881

3. Freeman MC, Patel V, Collins PY, Bertolote JM. Integrating mental health in global initiatives for HIV/AIDS. Br J Psychiatry. 2005;187 (1):1-3. doi:10.1192/bjp.187.1.1

4. Weiss RA. How does HIV cause AIDS? Science. 1993;260 (5112):1273-1279. doi:10.1126/science.8493571

5. Phair J, Jacobson L, Detels R, et al. Acquired immune deficiency syndrome occurring within 5 years of infection with human immunodeficiency virus type-1: the multicenter AIDS cohort study. J Acquir Immune Defic Syndr. 1992;5(5):490-496. doi:10.1097/ 00126334-199205000-00010

6. Kaye BR. Rheumatologic manifestations of infection with human immunodeficiency virus (HIV). Ann Intern Med. 1989;111 (2):158-167. doi:10.7326/0003-4819-111-2-158

7. Organization WH. Guidelines on Co-Trimoxazole Prophylaxis for HIV-Related Infections Among Children, Adolescents and Adults in Resource-Limited Settings: Recommendations for a Public Health Approach. 2006.

8. Girum T, Wasie A, Worku A. Trend of HIV/AIDS for the last 26 years and predicting achievement of the 90-90-90 HIV prevention targets by 2020 in Ethiopia: a time series analysis. BMC Infect Dis. 2018;18(1):320. doi:10.1186/s12879-018-3214-6

9. Global H. AIDS Statistics-2019 Fact Sheet (2019). 2020.

10. Mitiku A, Ayele TA, Assefa M, Tariku A. Undernutrition and associated factors among adults living with human immune deficiency virus in Dembia district, northwest Ethiopia: an institution based cross-sectional study. Arch Public Health. 2016;74(1):33. doi:10.1186/s13690-016-0143-y

11. Fletcher CV, Staskus K, Wietgrefe SW, et al. Persistent HIV-1 replication is associated with lower antiretroviral drug concentrations in lymphatic tissues. Proc Natl Acad Sci $U$ S A. 2014;111 (6):2307-2312. doi:10.1073/pnas.1318249111

12. May MT, Gompels M, Delpech V, et al. Impact on life expectancy of HIV-1 positive individuals of CD4+ cell count and viral load response to antiretroviral therapy. AIDS. 2014;28(8):1193. doi:10.1097/QAD.0000000000000243

13. Ethiopia MoH. National Comprehensive HIV Prevention, Care and Treatment Training for Pharmacy Professionals, Participant Manual. Ethiopia: Ministry of Health, Ethiopia. Geneva: UNAIDS; 2018.

14. Anema A, Vogenthaler N, Frongillo EA, Kadiyala S, Weiser SD. Food insecurity and HIV/AIDS: current knowledge, gaps, and research priorities. Curr HIV/AIDS Rep. 2009;6(4):224-231. doi:10.1007/s11904-009-0030-z

15. Organization WH. Nutrient Requirements for People Living with HIV/AIDS: Report of a Technical Consultation, 13-15 May 2003 Geneva; 2004. 
16. Anabwani G, Navario P. Nutrition and HIV/AIDS in sub-Saharan Africa: an overview. Nutrition. 2005;21(1):96-99. doi:10.1016/j. nut.2004.09.013

17. Garcia-Prats AJ, McMeans AR, Ferry GD, Klish WJ. Nutrition and HIV/AIDS. HIV Curric. 2010;286:4-5.

18. Ivers LC, Cullen KA, Freedberg KA, et al. HIV/AIDS, undernutrition, and food insecurity. Clin Infect Dis. 2009;49(7):1096-1102. doi:10.1086/605573

19. Hadgu TH, Worku W, Tetemke D, Berhe H. Undernutrition among HIV positive women in Humera hospital, Tigray, Ethiopia, 2013: antiretroviral therapy alone is not enough, cross sectional study. BMC Public Health. 2013;13(1):943. doi:10.1186/1471-2458-13-943

20. Cantrell RA, Sinkala M, Megazinni K, et al. A pilot study of food supplementation to improve adherence to antiretroviral therapy among food insecure adults in Lusaka, Zambia. J Acquir Immune Defic Syndr. 2008;49(2). doi:10.1097/QAI.0b013e31818455d2.

21. Gezahegn E, Edris M, Dachew BA. Prevalence and factors associated with undernutrition among adults with major depressive disorder in Northwest Ethiopia. Psychiatry J. 2016;2016:1-7. doi:10.1155/2016/ 7034582

22. Kenea MA, Garoma S, Gemede HF. Assessment of adult nutritional status and associated factors among ART users in Nekemte referral hospital and health center, east Wollega zone, Ethiopia. J Food Nutr Sci. 2015;3(2):56-63.

23. Gedle D, Gelaw B, Muluye D, Mesele M. Prevalence of malnutrition and its associated factors among adult people living with HIV/AIDS receiving anti-retroviral therapy at Butajira Hospital, southern Ethiopia. BMC Nutr. 2015;1(1):1-11. doi:10.1186/2055-0928-1-5

24. Oumer B, Boti N, Hussen S, Gultie T. Prevalence of under nutrition and associated factors among adults receiving first-line antiretroviral treatment in public health facilities of Arba Minch Town, Southern Ethiopia. HIV AIDS (Auckl). 2019;11:313.

25. Gebremichael DY, Hadush KT, Kebede EM, Zegeye RT. Food insecurity, nutritional status, and factors associated with malnutrition among people living with HIV/AIDS attending antiretroviral therapy at public health facilities in West Shewa Zone, Central Ethiopia. Biomed Res Int. 2018;2018:1-9. doi:10.1155/2018/1913534

26. Thapa R, Amatya A, Pahari DP, Bam K, Newman MS. Nutritional status and its association with quality of life among people living with HIV attending public anti-retroviral therapy sites of Kathmandu Valley, Nepal. AIDS Res Ther. 2015;12(1):14. doi:10.1186/s12981015-0056-9

27. Benzekri NA, Sambou J, Diaw B, et al. High prevalence of severe food insecurity and malnutrition among HIV-infected adults in Senegal, West Africa. PLoS One. 2015;10(11):e0141819. doi:10.1371/journal.pone.0141819

28. Kabalimu TK, Sungwa E, Lwabukuna WC. Malnutrition and associated factors among adults starting on antiretroviral therapy at PASADA Hospital in Temeke District, Tanzania. Tanzan J Health Res. 2018;20(2).
29. Dedha M, Damena M, Egata G, Negesa L. Undernutrition and associated factors among adults human immunodeficiency virus positive on antiretroviral therapy in hospitals, East Hararge Zone, Oromia, Ethiopia: a cross-sectional study. Int J Health Sci (Qassim). 2017;11 (5):35-42.

30. Teshome MS, Gissa SB, Tefera BZ, Lema TB. Undernutrition and its predictors among people living with HIV/AIDS attending antiretroviral therapy clinic in Jimma University Specialized Hospital. Int J Nutr Metab. 2017;9(8):67-74.

31. Amza L, Demissie T, Halala Y. Under nutrition and associated factors among adult on highly active antiretroviral therapy in Wolaita Sodo teaching and referral hospital, southern nations nationalities peoples region, Ethiopia. Int J Nutr Metab. 2017;9(2):10-19. doi:10.5897/ IJNAM2016.0208

32. Asnakew M, Suzuki A, VonVille H, Hixson JE, Iwata J. Malnutrition and associated factors among adult individuals receiving highly active antiretroviral therapy in health facilities of Hosanna Town, Southern Ethiopia. Open Access Lib J. 2015;2(01):1. doi:10.4236/ oalib. 1101583

33. Andrade CS, Jesus RP, Andrade TB, Oliveira NS, Nabity SA, Ribeiro GS. Prevalence and characteristics associated with malnutrition at hospitalization among patients with acquired immunodeficiency syndrome in Brazil. PLoS One. 2012;7(11):e48717. doi:10.1371/journal.pone.0048717

34. Hailemariam S, Bune GT, Ayele HT. Malnutrition: prevalence and its associated factors in people living with HIV/AIDS, in Dilla University Referral Hospital. Arch Public Health. 2013;71(1):13. doi:10.1186/0778-7367-71-13

35. Takarinda KC, Mutasa-Apollo T, Madzima B, et al. Malnutrition status and associated factors among HIV-positive patients enrolled in ART clinics in Zimbabwe. BMC Nutr. 2017;3(1):15. doi:10.1186/ s40795-017-0132-8

36. Mengesha Kassie A, Beletew Abate B, Wudu Kassaw M, Gebremeskel Mesafint T. Prevalence of underweight and its associated factors among reproductive age group women in ethiopia: analysis of the 2016 Ethiopian demographic and health survey data. $J$ Environ Public Health. 2020;2020:1-10. doi:10.1155/2020/ 9718714

37. Halala Y. Prevalence of stunting and associated factors among children aged 6 to 59 months in Areka town, Wolaita Zone, Southern Ethiopia. Prevalence. 2016;21.

38. Tang AM, Sheehan HB, Jordan MR, et al. Predictors of weight change in male HIV-positive injection drug users initiating antiretroviral therapy in Hanoi, Vietnam. AIDS Res Treat. 2011;2011:1-8. doi:10.1155/2011/890308

39. Huis D, Balestre E, Buyze J. Determinants of weight evolution among HIV-positive patients initiating antiretroviral treatment in low resource settings. J Acquir Immune Defic Syndr. 2015;70 (2):146. doi:10.1097/QAI.0000000000000691

\section{Publish your work in this journal}

HIV/AIDS - Research and Palliative Care is an international, peerreviewed open-access journal focusing on advances in research in HIV, its clinical progression and management options including antiviral treatment, palliative care and public healthcare policies to control viral spread. The manuscript management system is completely online and includes a very quick and fair peer-review system, which is all easy to use. Visit http://www.dovepress.com/testimonials.php to read real quotes from published authors. 